\title{
Black soldier flies (Hermetia illucens Linnaeus) as recyclers of organic waste and possible livestock feed
}

\author{
Paulin NANA ${ }^{1 *}$, Janaina Mitsue KIMPARA ${ }^{2}$, Christian Keambou TIAMBO ${ }^{3}$, \\ Claudine Tekounegning TIOGUÉ ${ }^{1}$, Jislaire YOUMBI ${ }^{1}$, Boniface CHOUNDONG ${ }^{1}$ and \\ Théophile FONKOU ${ }^{4}$
}

\author{
${ }^{1}$ School of Wood, Water and Natural Resources, Faculty of Agriculture and Agricultural Sciences, \\ University of Dschang, Ebolowa Campus, PO Box 786 Ebolowa, Cameroon. \\ ${ }^{2}$ Brazilian Agricultural Research Corporation (EMBRAPA), Embrapa Meio-Norte, Parnaíba, PI, Brazil. \\ ${ }^{3}$ Department of Animal Science, Faculty of Agriculture and Veterinary Medicine, \\ University of Buea, Cameroon. \\ ${ }^{4}$ Department of Botany, Faculty of Science, University of Dschang, PO Box 63 Dschang, Cameroon. \\ ${ }^{*}$ Corresponding author; E-mail: paulin.nana@univ-dschang.org; Phone: +237 678595440
}

\section{ACKNOWLEDGEMENTS}

This work was supported by funds from the EMBRAPA-Brazil, provided for the execution of the ID 2341 Africa Brazil Agricultural Innovation Marketplace project.

\begin{abstract}
Valorisation of organic waste through larval feeding activity of the Black Soldier Fly (BSF), Hermetia illucens, constitutes a potential benefit for low- and middle-income countries. BSF larvae feed on organic waste while building their body composition of protein and fat. As a response to the escalating demand for protein in livestock feed, their protein can be used to replace fishmeal in monogastric animals' diet. Experiments were carry out to evaluate the feasibility of Black Soldier Fly (BSF) Hermetia illucens Linnaeus larvae to digest and degrade organic waste in a small-scale. Organic wastes (pig and chicken manures and kitchen wastes) were introduced in basins with 2000 young larvae (3-5 day-old) per basin for 15 days in batch and continuous feeding. We achieved an average pre-pupae production 830.1 and $694.0 \mathrm{~g} / \mathrm{m}^{2}$ (wet weight) under favourable conditions respectively in continuous and in batch feedings. Larvae fed every three days with waste materials developed into significantly larger larvae and pre-pupae than those fed at once. Waste reduction ranged from 53 to $80 \%$ depending on the daily amount of waste added to the experimental unit. The bioconversion rates were $12.8 \%, 10.7 \%$ and $6.5 \%$ respectively for chicken manure, pig manure and kitchen at the feeding ratio of $220 \mathrm{mg} / \mathrm{day} / \mathrm{larvae}$ in continuous feeding. This study confirmed the great potential of BSF as a component of waste management in low and middle-income countries. If applied in organic waste management chain, the process could contribute to generate biofuel energy as well as sustainable protein provision to the animal industries. It could further reduce waste amounts significantly, minimizing possible pollution and improving environmental sanitation.
\end{abstract}

(C) 2018 International Formulae Group. All rights reserved.

Keywords: Hermetia illucens, organic waste, waste reduction, bioconversion, protein. 


\section{INTRODUCTION}

The world's population peaked at six billion people just before the turn of the millennium, and the most up-to-date estimates suggest that global population will increase by another 2.5 billion to a total of 9.2 billion in 2050. Most of this increase will be in less developed regions of the world, where population is projected to rise from 5.4 billion now to 7.9 billion in 2050 (FAO, 2009; IFAD 2012). The paradox is that while the world population continues to grow along with resource consumption and waste generation, the resources are becoming limited, triggering various responses from different sectors of society. There is need for consented efforts from all sectors in solving this paradox, more so to ensure reduced resource use, consumption and waste generation.

Conversion of organic waste into compost by saprophages such as earthworms and microorganisms is well-documented (Suthar and singh, 2008). In many developing countries, waste collection and disposal is an ever-increasing environmental health problem and it is believed that one- to two-thirds of waste is many countries are not collected (Diener et al., 2009). Insects such as the black soldier fly (BSF) (Hermetia illucens Linnaeus) and the common house fly (Musca domestica Linnaeus) can play a significant role in conversion of organic waste streams into biofertilizer, animal and fish feed while contributing to sustainable management of the environment (Nguyen et al., 2015). BSF is a particularly interesting candidate - it has been demonstrated to convert dairy, poultry, and swine manure to body mass (reducing dry matter mass by up to 58\%) (Rheman et al., 2017). Although problems such as mass rearing, automation and food safety needs to be addressed, there is the need to also explore the potential of using other insect species for the same purpose.

Black soldier fly larvae prosper in large numbers on organic wastes (coffee bean pulp, vegetables, brewery waste and fish offal) and manure pile of poultry, pigs and cattle and can be used commercially to solve several environmental problems associated with manure and other organic waste (e.g. reducing manure mass, moisture content and offensive odours) (Diener et al., 2009). It has been demonstrated that soldier flies can reduce dry matter mass of dairy, poultry, and swine manure to the body mass, by up to $58 \%$ and associated nutrients such as $\mathrm{P}$ and $\mathrm{N}$ by 61-70\% and 30-50\%, respectively (Meyers et al., 2008). Adult black soldier flies are not attracted to human habitats or foods and not constitute a nuisance.

In the waste management chain, there have been value addition efforts where wastes have been transformed to other valuable resources, thereby reducing the need for fresh raw materials. One such approach is in the BSF bioconversion of organic wastes. Organic wastes such as animal wastes, household wastes, commercial wastes (from stores, shops, markets, hotels, etc.) and institutional wastes (schools, hospitals, etc.) are usually generated in large quantities, and are potential environmental pollutants and human health hazards if not handled well ( $\mathrm{Li}$ et al., 2011). Not only do we jeopardise our health and that of the environment when we don't take good care of our waste, we also lose on the economic benefit thereof. Food and other organic wastes are a valuable resource that we shouldn't waste as it contains a lot of nutrients and energy value that could be beneficial to both humans and the environment if reintegrated into the value chain (Bloukounon-Goubalan et al., 2017).

On the issue of provision of protein for feed, it has been noted that as the world population continues to grow, there is need to produce more food. This has pushed the livestock sector to increase their yield at the expense of the environment (Nyadjeu et al., 2018) in most cases as the production will have to increase by $70 \%$ to be able to feed the 
world in 2050 (Van Huis, 2013; Fomekong et al., 2018). At the same time, FAO (2006) comes on board and reports that during this up-scaled food and feed production, especially with livestock, water is depleted and polluted, land degraded and biodiversity destroyed, and climate change and pollution increased. It further points out that a cow, for example, consumes $75-300 \mathrm{~kg}$ of grass or grain just to produce $1 \mathrm{~kg}$ of protein. This translates to high carbon footprints that need to be reduced. Apparently, the BSF process and its byproducts seem like a step in the right direction in curbing these carbon footprints, and so this study is embarked on.

This study aimed at evaluating the capability of the black soldier fly larvae to digest and degrade various organic waste and thus determine the feasibility of using it for sustainable organic waste treatment.

\section{MATERIALS AND METHODS}

\section{Black soldier fly colony and study site}

The colony of black soldier fly started with 2000 pre-pupae imported from International Centre of Insect Physiology and Ecology (ICIPE) Nairobi, Kenya. The prepupae were maintained in a small screen house ( $4 \times 3 \times 2 \mathrm{~m})$ roofed with transparent plastic foil fitted with nylon net. Pre-pupae were kept in a plastic bucket at ambient temperature $\left(28.3 \pm 2{ }^{\circ} \mathrm{C}\right)$ without feed till pupation. The breeding started in June 2016 and lots of parameters such as humidity, temperature and space requirements were controlled. The experiments were carried out at the University of Dschang, Ebolowa Campus premises, (Ebolowa, Cameroon): $2^{\circ} 55^{\prime} 41^{\prime \prime} \mathrm{N}, 11^{\circ} 9^{\prime} 19^{\prime \prime}, 724 \mathrm{~m}$ asl. In green house, a black polythene foil was used to cover the bucket $(\varnothing 0.6 \mathrm{~m} \times 0.2 \mathrm{~m})$ containing organic waste used to attract ovipositing females. The method for collecting eggs was adapted from (Tomberlin et al., 2009). Strips of corrugulated cardboard $(15 \times 4 \mathrm{~cm}$, flute opening $2 \times 5 \mathrm{~mm}$ ) were wrapped and pined into the basins. The cardboard strips were collected every two days and inserted into nylon covered plastic dishes containing wet chicken feed. These hatching containers were stored in the dark and warm environment $\left(28.3 \pm 2{ }^{\circ} \mathrm{C} ; 80 \% \mathrm{RH}\right)$. Larvae hatched approximately 3 days after oviposition and dropped from the cardboard strips into the wet chicken feed. The young larvae were then used at the age of 3-5 days to inoculate the experimental setup. To supply the colony with new adults, 500 pre-pupae from every experiment's harvest were placed into plastic bucket ( $\varnothing 35 \mathrm{~cm} \times 20 \mathrm{~cm}$ ), were they pupated in a mixture of hay and wood shavings. Emerging adults were released in a wooden cage fitted with plastic mesh all around, except for the bottom which was fitted with a wooden board that could serve as a door.

\section{Experimental design}

In a first experiment where waste was provided at once to BSF larvae (batch feeding), six-liter buckets were weighed and labelled to include feeding regime and replicate number. Prior to distribution of organic wastes, the samples were combined and mixed thoroughly in a large bowl to remove variation between samples. The experiments consisted of 3 feeding regimes (100, 160, $220 \mathrm{mg}$ of waste/larvae/day) (Table 1). The quantity of waste was determined according to the optimal feed ratio of $100 \mathrm{mg}$ of waste/larvae/day (Diener et al., 2011). The empty weight of the feeding bucket would be taken, after which the predetermined amount of waste would be added all at once. Organic wastes (pig and chicken manures and kitchen wastes) and 2000 larvae of the same age were weighed and applied to each treatment. The buckets was then placed in cages made with wood frame and fitted with plastic net, to protect the experience from mild disturbances like other insects which will come to lay eggs. The duration of the experiment is established 
according to the time that the larvae need to reach full maturity, which is about 15 days.

In a second experiment, the supply of waste to BSF larvae was continuous. Waste was added to the feeding buckets periodically as opposed to the one off addition as previously described. The continuous feeding would mean adding $300 \mathrm{mg}$ of the organic waste at the beginning of the feeding regime, and there after adding another $600 \mathrm{mg}$ at 3day intervals to finally reach $3.3 \mathrm{~kg}$ feeding capacity for 2000 larvae. Once ready (approximately 15 days after), the pre-pupae would become restless, seeking to come out of the buckets as they looked for a drier and darker place to pupate. All the pre-pupae were collected and weighed. It was not necessary to wash the larvae before weighing, as it was shown in a preliminary experiment that washing did not significantly alter larval weight (Banks, 2010).

\section{Biomass conversion}

Bioconversion, a very important aspect in the BSF technology, depends on the amount of food consumed and the efficiency of the consumption. It is explained by Prepupal Weight (PW), Waste Reduction (WR), Bioconversion Rate (BR) and Feed Conversion Rate (FCR), which are calculated as follow: (1) Prepupal Weight (PW) (wet weight) is the actual weight of the pre-pupae after feeding; (2) Waste Reduction (WR) is the percentage of the diet consumed on a dry matter basis, and is calculated as:

$\mathrm{WR}(\%)=[1-($ Feed Residue $/$ Feed Added $)] \times 100)]$; (3) Bioconversion Rate (BR) is the quantity of the diet converted to pre-pupae biomass expressed as a percentage, and is calculated as:

$\mathrm{BR}(\%)=($ Prepupal Weight $/$ Feed Added $) \times 100$; (4)

Feed Conversion Rate (FCR) is the ratio of the feed consumed to the total Pre-pupal weight or biomass, and is calculated as: FCR $=$ Feed consumed/Prepupal Weight (Zhou et al., 2013, Banks et al., 2014).

\section{Data analysis}

Analysis of variance (ANOVA) was used to determine significant differences between feeding regimes, and between groups within the same feeding regime. Mean comparison was carried out using StudentNewman-Keuls test. A Student's t-test was used to compare parameters such as pre-pupal weight and waste reduction between batch and continuous feeding at $\mathrm{P}=0.05$ significance level. Percentage data were transformed, depending on range (Parsad, 2005). The variables comprised total feed added, total residue, waste reduction, pre-pupal mean weight, percentage pupation and pre-pupal yield. The bioconversion and FCR were calculated for actual yield and an estimated 95\% harvest.

Table 1: Description of Hermetia illucens feeding regime used in the experiments.

\begin{tabular}{|c|c|c|c|c|c|c|}
\hline \multirow{2}{*}{$\begin{array}{l}\text { Parameters } \\
\text { Feeding ratio mg/larvae/day }\end{array}$} & \multicolumn{3}{|c|}{ Batch feeding } & \multicolumn{3}{|c|}{ Continuous feeding } \\
\hline & 100 & 160 & 220 & 100 & 160 & 220 \\
\hline Number of larvae (n) & 2000 & 2000 & 2000 & 2000 & 2000 & 2000 \\
\hline Quantity of feed/waste (kg) & 1.50 & 2.40 & 3.30 & 1.50 & 2.40 & 3.30 \\
\hline Feeding occasions $(\mathrm{n})$ & \multicolumn{3}{|c|}{$\begin{array}{c}1 \text { (At the beginning of the } \\
\text { experiment) }\end{array}$} & \multicolumn{3}{|c|}{5 (every 3 days) } \\
\hline Treatment replicates $(\mathrm{n})$ & 6 & 6 & 6 & 6 & 6 & 6 \\
\hline
\end{tabular}




\section{RESULTS}

\section{Black soldier fly colony establishment}

A black soldier fly colony was successfully established. A mean daytime temperature of $28.6{ }^{\circ} \mathrm{C}$ provided optimal conditions for reproduction, and fly larvae could tolerate a wide range of temperatures in feeding basins $\left(18-42{ }^{\circ} \mathrm{C}\right)$. In batch feeding, there were significant differences between mean larval weights in all treatments.

\section{Efficacy of biomass conversion}

The pre-pupal weights were dependent on the food source and the feeding ratio. In feeding ratio $100 \mathrm{mg} /$ larvae/day, the highest pre-pupal wet weight $(142.6 \pm 3.4 \mathrm{~g})$ was obtained with chicken manure followed by pig manure $(130.8 \pm 4.1 \mathrm{~g})$ and the lowest $(120.3 \pm$ $5.1 \mathrm{~g}$ ) was recorded with the kitchen waste (Table 2). Similar trend was recorded with the feeding ratio 160 and $220 \mathrm{mg} / \mathrm{larvae} / \mathrm{day}$. The larvae in the feeding ratio $220 \mathrm{mg} / \mathrm{larvae} / \mathrm{day}$ were significantly larger $(\mathrm{P}<0.05)$ than in others feeding ratio (Table 2). The bioconversion rates for all the treatments and waste sources ranged between 5.5 and $10.5 \%$. Chicken manure registered the highest bioconversion rate $(10.5 \%)$ while kitchen waste registered the lowest $(5.5 \%)$. The highest feed conversion ratio was recorded with pig manure (8.7) in batch feeding and the lowest (6.7) was recorded with kitchen waste. For waste reduction, the highest $(75.7 \%)$ was recorded with chicken manure and the lowest $(53.7 \%)$ recorded with kitchen waste.

In continuous feeding, chicken manure with feeding regime $220 \mathrm{mg} /$ day/larvae was the best in producing larval biomass $(401.9 \pm$ $2.2 \mathrm{~g})$, followed by pig manure $(351.6 \pm 3.8 \mathrm{~g})$ and kitchen waste $(215.2 \pm 4.9 \mathrm{~g})$. Waste reduction data were recorded between 50.7 and $80.0 \%$. Differences between all treatments were significant $(\mathrm{P}<0.001)$. The lowest percentage of waste reduction $(50.7 \%)$ was recorded with kitchen waste at the feeding regime $100 \mathrm{mg} / \mathrm{larvae} /$ day. This was significantly $(\mathrm{F}=26.7, \mathrm{P}<0.001, \mathrm{df}=2)$ lower than 65.1 and $79.7 \%$ recorded in pig and chicken waste respectively at the same treatment. In the feeding regime 220 $\mathrm{mg} /$ larvae/day, the highest waste reduction (80\%) was recorded with chicken manure as compared with pig manure (69.5\%) and kitchen $(72.4 \%)$ wastes $(\mathrm{F}=9.4, \mathrm{P}<0.002$, $\mathrm{df}=2$ ). The trend was similar with the other feeding ratios (Table 3). The highest feed conversion rate $(12.8 \%)$ was registered with chicken manure at the feeding ratio of 220 $\mathrm{mg} / \mathrm{larvae} /$ day while the lowest $(6.5 \%)$ was recorded with kitchen waste at the same treatment. The highest feed conversion ratio (15.3) was recorded with kitchen waste and the lowest feed conversion ratio (8.2) was registered with chicken manure.

Pre-pupal weight was significantly higher in continuous feeding for all the treatments when compared with batch feeding (Figure 1A, 1B and 1C). There was no significant difference in pig, chicken and kitchen waste reduction between batch and continuous feeding (Figure 2A, 2B and 2C). Feed conversion ratios were significantly high in continuous feeding when compared with batch feeding which recorded significantly low indices. For example, in continuous feeding, the feed conversion ratio of 15.3 in chicken manure was recorded while for the same treatment in batch feeding, the feed conversion ratio was 8.2 . 
P. NANA et al. / Int. J. Biol. Chem. Sci. 12(5): 2004-2015, 2018

Table 2: Biomass conversion parameters depending on feeding regimes (pig, chicken and kitchen wastes) in batch feeding.

\begin{tabular}{|c|c|c|c|c|c|c|c|c|c|}
\hline \multirow{3}{*}{$\begin{array}{l}\text { Biomass conversion } \\
\text { parameters }\end{array}$} & \multicolumn{9}{|c|}{ Feeding regimes mg/larvae/day } \\
\hline & \multicolumn{3}{|c|}{100} & \multicolumn{3}{|c|}{$\begin{array}{r}160 \\
\end{array}$} & \multicolumn{3}{|c|}{220} \\
\hline & Pig & Chicken & Kitchen & Pig & Chicken & Kitchen & Pig & Chicken & Kitchen \\
\hline Feed added $(\mathrm{g})$ & 1500 & 1500 & 1500 & 2400 & 2400 & 2400 & 3300 & 3300 & 3300 \\
\hline Pre-pupae wet weight (g) & $130.8 \pm 4.1 \mathrm{a}$ & $142.6 \pm 3.4 b$ & $120.3 \pm 5.1 \mathrm{c}$ & $210.5 \pm 6.2 \mathrm{a}$ & $251.2 \pm 4.7 \mathrm{~b}$ & $151.4 \pm 3.3 \mathrm{c}$ & $251.7 \pm 4.1 \mathrm{a}$ & $310.5 \pm 2.4 b$ & $181.2 \pm 6.6 \mathrm{c}$ \\
\hline Residue (g) & $550.7 \pm 3.2 \mathrm{a}$ & $364.7 \pm 5.3 b$ & $694.2 \pm 4.3 \mathrm{c}$ & $911.3 \pm 3.1 \mathrm{a}$ & $621.4 \pm 7.2 b$ & $820.1 \pm 4.7 c$ & $1110.8 \pm 4.3 \mathrm{a}$ & $824.8 \pm 5.1 b$ & $1069.6 \pm 5.0 \mathrm{c}$ \\
\hline Feed consumed $(\mathrm{g})$ & $949.3 \pm 2.2 \mathrm{a}$ & $1135.3 \pm 1.1 b$ & $805.8 \pm 3.8 \mathrm{c}$ & $1488.7 \pm 6.1 \mathrm{a}$ & $1778.6 \pm 4.2 b$ & $1579.9 \pm 5.3 c$ & $2189.2 \pm 7.1 \mathrm{a}$ & $2475.2 \pm 3.9 b$ & $2230.4 \pm 4.6 c$ \\
\hline Waste reduction (ww) (\%) & $63.3 \pm 2.1 \mathrm{a}$ & $75.7 \pm 3.3 b$ & $53.7 \pm 2.4 \mathrm{c}$ & $62.0 \pm 3.8 \mathrm{a}$ & $74.1 \pm 4.6 \mathrm{~b}$ & $58.0 \pm 6.2 \mathrm{c}$ & $66.3 \pm 2.8 \mathrm{a}$ & $75.0 \pm 5.1 \mathrm{~b}$ & $67.8 \pm 3.1 \mathrm{c}$ \\
\hline $\mathrm{BR}(\%)$ & $8.7 \pm 0.4 \mathrm{a}$ & $9.5 \pm 0.2 b$ & $8.0 \pm 1.1 \mathrm{a}$ & $8.7 \pm 0.1 \mathrm{a}$ & $10.5 \pm 0.3 b$ & $7.7 \pm 0.9 \mathrm{a}$ & $7.6 \pm 0.4 \mathrm{a}$ & $9.4 \pm 0.6 b$ & $5.5 \pm 1.5 c$ \\
\hline FCR & 7.3 & 8.0 & 6.7 & 7.1 & 7.1 & 7.5 & 8.7 & 8.0 & 8.2 \\
\hline
\end{tabular}

Means followed by the same letter are not significantly different P < 0.05 (ANOVA); BR: Bioconversion Rate, FCR: Feed Conversion Ratio

Table 3: Biomass conversion parameters depending on feeding regimes (pig, chicken and kitchen wastes) in continuous feeding.

\begin{tabular}{|c|c|c|c|c|c|c|c|c|c|}
\hline \multirow{3}{*}{$\begin{array}{l}\text { Biomass conversion } \\
\text { parameters }\end{array}$} & \multicolumn{9}{|c|}{ Feeding regimes mg/larvae/day } \\
\hline & \multicolumn{3}{|c|}{100} & \multicolumn{3}{|c|}{160} & \multicolumn{3}{|c|}{220} \\
\hline & Pig & Chicken & Kitchen & Pig & Chicken & Kitchen & Pig & Chicken & Kitchen \\
\hline Feed added $(\mathrm{g})$ & 1500 & 1500 & 1500 & 2400 & 2400 & 2400 & 3300 & 3300 & 3300 \\
\hline Pre-pupae wet weight (g) & $129.4 \pm 5.2 \mathrm{a}$ & $153.8 \pm 3.5 b$ & $123.6 \pm 4.7 \mathrm{a}$ & $254.4 \pm 5.2 \mathrm{a}$ & $288.5 \pm 3.7 b$ & $173.6 \pm 2.1 \mathrm{c}$ & $351.6 \pm 3.8 \mathrm{a}$ & $401.9 \pm 2.2 b$ & $215.2 \pm 4.9 c$ \\
\hline Residue (g) & $523.4 \pm 4.2 \mathrm{a}$ & $304.8 \pm 5.3 b$ & $739.4 \pm 6.3 c$ & $812.3 \pm 4.8 \mathrm{a}$ & $588.2 \pm 7.3 b$ & $767.6 \pm 5.1 \mathrm{c}$ & $1007.1 \pm 5.4 \mathrm{a}$ & $658.8 \pm 6.1 b$ & $911.3 \pm 6.2 \mathrm{c}$ \\
\hline Feed consumed $(\mathrm{g})$ & $976.6 \pm 7.9 \mathrm{a}$ & $1195.2 \pm 5.1 b$ & $760.6 \pm 3.7 \mathrm{c}$ & $1587.7 \pm 7.5 \mathrm{a}$ & $1811.8 \pm 4.1 b$ & $1632.4 \pm 5.9 \mathrm{c}$ & $2292.9 \pm 8.3 \mathrm{a}$ & $2641.2 \pm 4.2 b$ & $2388.7 \pm 7.2 \mathrm{c}$ \\
\hline Waste reduction (ww) (\%) & $65.1 \pm 3.3 \mathrm{a}$ & $79.7 \pm 5.1 b$ & $50.7 \pm 5.2 \mathrm{c}$ & $66.2 \pm 2.2 \mathrm{a}$ & $75.5 \pm 5.2 b$ & $68.0 \pm 4.2 \mathrm{a}$ & $69.5 \pm 5.2 \mathrm{a}$ & $80.0 \pm 4.3 b$ & $72.4 \pm 3.2 \mathrm{a}$ \\
\hline $\mathrm{BR}(\%)$ & $8.6 \pm 0.3 \mathrm{a}$ & $10.3 \pm 0.3 b$ & $8.2 \pm 1.1 \mathrm{a}$ & $10.6 \pm 0.8 \mathrm{a}$ & $12.0 \pm 1.1 b$ & $7.2 \pm 0.4 \mathrm{c}$ & $10.7 \pm 0.9 \mathrm{a}$ & $12.8 \pm 1.5 b$ & $6.5 \pm 1.2 \mathrm{c}$ \\
\hline FCR & 11.6 & 9.8 & 12.1 & 9.4 & 8.3 & 13.8 & 9.4 & 8.2 & 15.3 \\
\hline
\end{tabular}

Means followed by the same letter are not significantly different P < 0.05 (ANOVA); BR: Bioconversion Rate, FCR: Feed Conversion Ratio. 

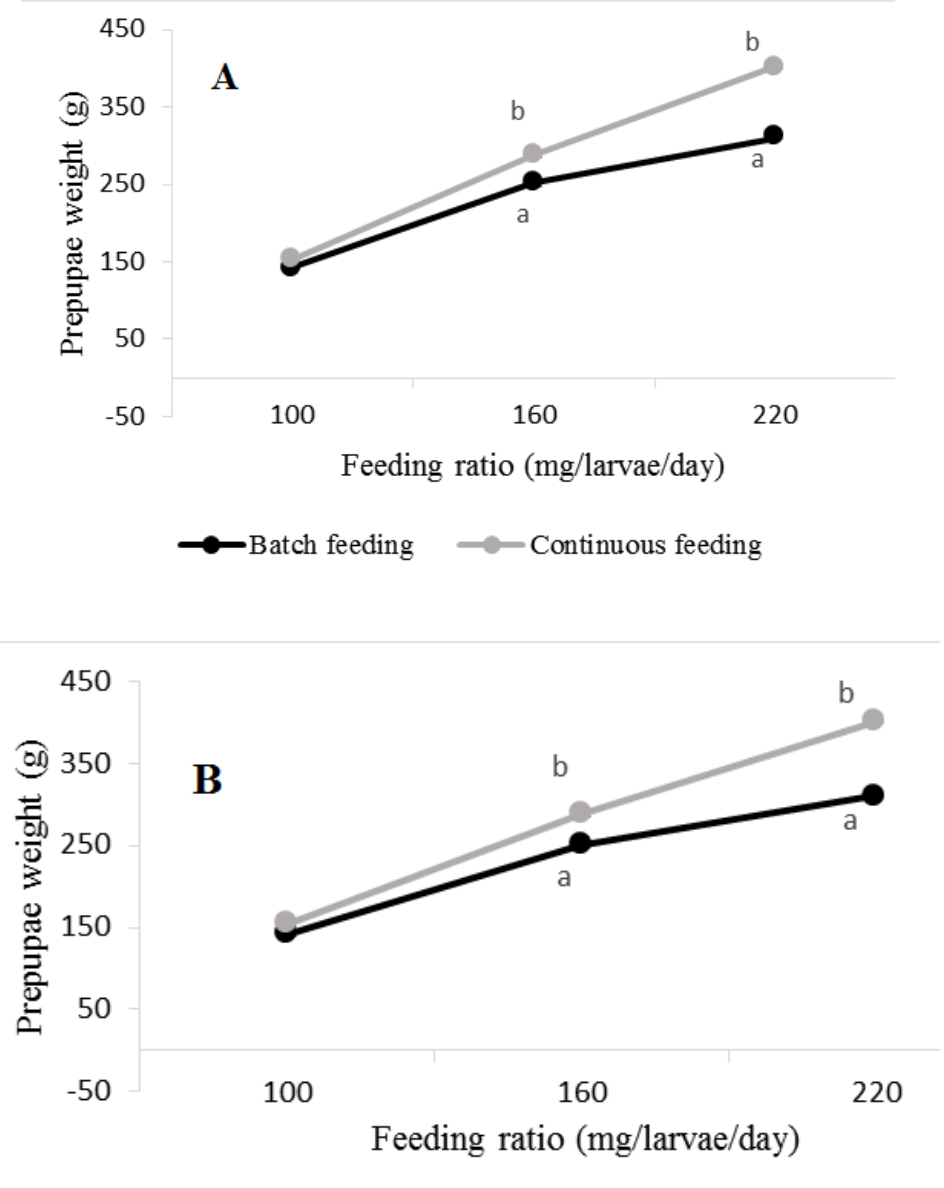

$\longrightarrow$ Batch feeding $\longrightarrow$ Continuous feeding

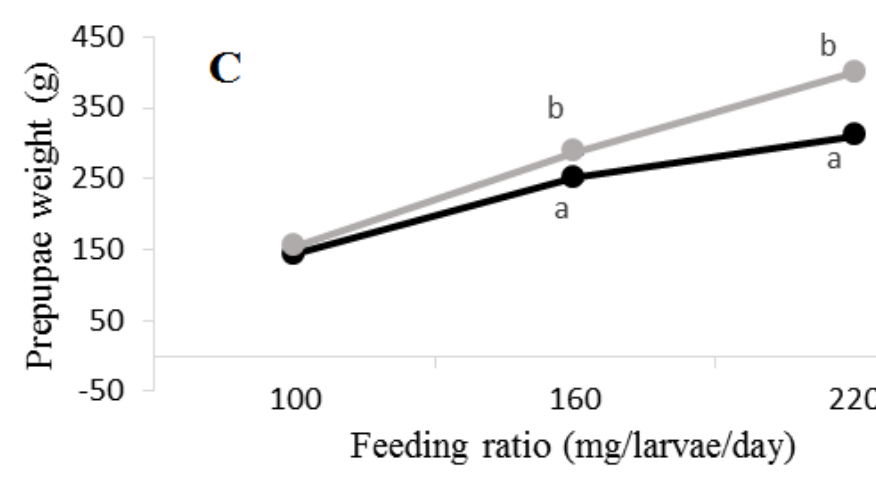

$\longrightarrow$ Batch feeding $\rightarrow$ Continuous feeding

Figure 1: Prepupae weight between batch feeding and continuous feedings with chicken manure (A), pig manure (B) and kitchen waste (C). 


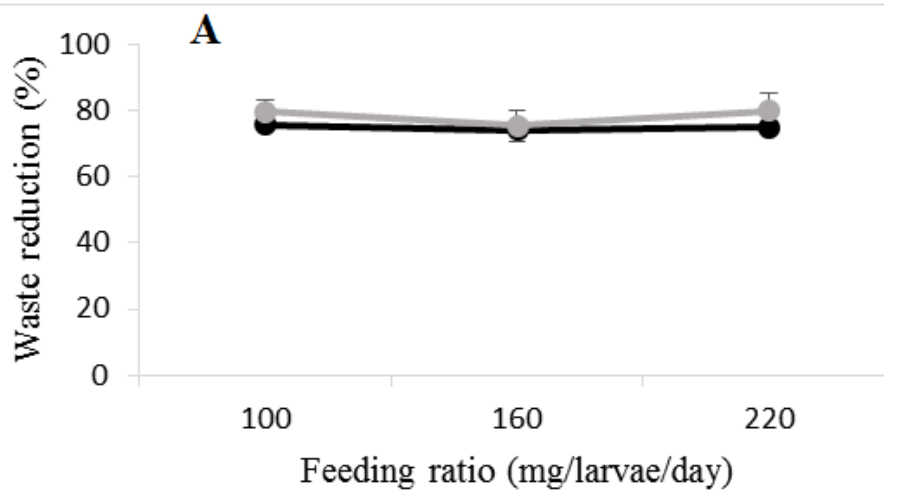

$\longrightarrow$ Batch feeding $\quad \longrightarrow$ Continuous feeding
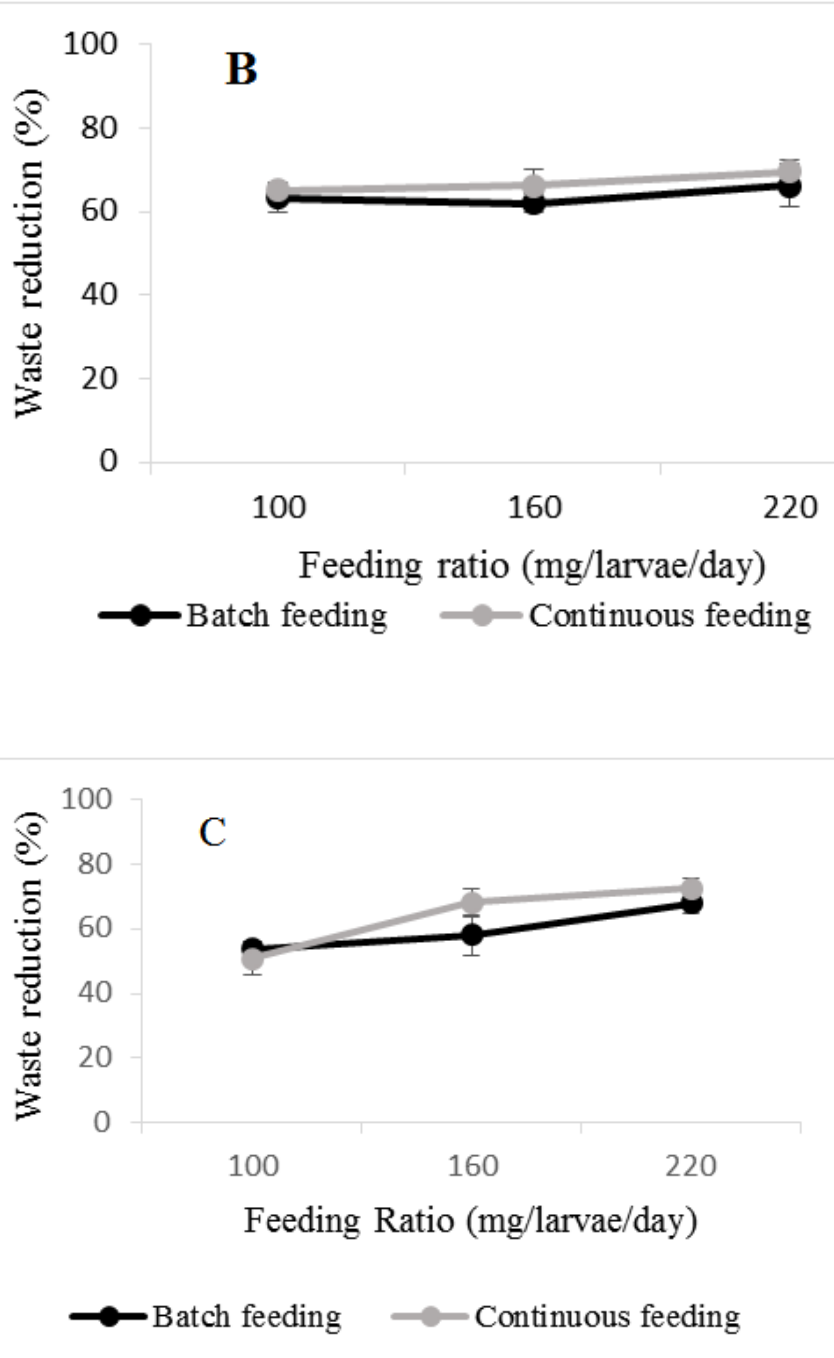

Figure 2: Waste reduction (\%) between batch and continuous feedings with chicken manure (A), pig manure (B) and kitchen waste (C). 


\section{DISCUSSION}

Black Soldier Fly (BSF) colony was successfully established. However, dealing with an innovative technology that relies on inoculation of living organisms for realisation of the desired output can be challenging. The establishment of BSF colony was only a step, as the focus was to efficiently consume organic wastes recycling nutrients into biomass and compost. In the present study, the average pre-pupae productions were 830.1 and $694.0 \mathrm{~g} / \mathrm{m}^{2}$ (wet weight) under favourable conditions respectively in continuous and in batch feedings. Waste reduction ranged from 53 to $80 \%$ depending on the daily amount of waste added to the experimental unit. Bioconversion of organic waste into compost by saprophages such as earthworms and microorganisms as well as waste reduction is well-documented (Suthar and singh, 2008; Pathma and Sakthivel, 2012). However, many laboratory studies showed BSF is well suited for biodegradation of organic waste (Banks et al., 2014, Cickova et al., 2015). BSF can play a significant role in conversion of organic waste streams into biomass and biofertilizer, while contributing to sustainable management of the environment.

The BSF fed with fresh waste every 3 days developed faster into large pre-pupae than the larvae fed at once. Based on the slow development of larvae fed at once, it was assumed that larvae have preference for fresh diet as compared with rotten diet. When fed at once, the larvae are overwhelmed with food to process and part of the food will rot due to microorganism breakdown and will contain less nutrient and larvae will have to consume more to compensate for deficient nutrients (Wright et al., 2003). Proteins and carbohydrates are critical in the development of the larvae (Simpson et al., 2006). Ageing feed material loses nutrients over time, and thus there is little nutrients to which larvae are exposed to (Banks et al., 2014). This could explain the reduced weight of pre-pupae in batch feeding when comparing with continuous feeding. However, there are few data regarding the protein and carbohydrate content of fresh or ageing waste from different sources. Valorization of this organic waste through larval feeding activity of the black soldier fly constitutes a potential benefit, especially for developing countries. The effective waste reduction was significantly high in treatment receiving chicken manure at the rate of $220 \mathrm{mg} / \mathrm{larvae} / \mathrm{day}$ in continuous feeding. The larvae could cope with the daily amount of waste fed. With a 0.26 larvae $/ \mathrm{cm}^{2}$ density, we achieved a daily feeding rate 176 $\mathrm{mg} / \mathrm{larvae} /$ day which is higher than $61 \mathrm{mg}$ of waste proposed by (Diener et al., 2009). BSF is a particularly interesting candidate for waste management because organic waste can be recycled into biofuel. Li et al. (2011) demonstrated the feasibility of converting organic waste into biodiesel using BSF larvae.

Biomass conversion was discussed in terms of bioconversion rates, feed conversion ratio, pre-pupal weights and waste reductions among the three different waste streams. Prepupae from the chicken manure performed best in bioconversion rate (BR), feed conversion ratio (FCR) and pre-pupae weight (PW) in these experiments while kitchen stream performed least in all parameters. This implies that chicken manure, follow by pig manure were more effective in terms of biomass reduction as well as more efficient in terms of feed conversion into biomass. Manure streams, with the composition of $41 \%$ protein and $13 \%$ fat, the protein could explain the difference in characteristics when compared with natural composting (Biekre et al. 2018). It has been demonstrated that BSF can reduce waste of dairy, poultry and swine manure to body mass, by up to $58 \%$ and associated nutrients such as $\mathrm{P}$ and $\mathrm{N}$ by 61 $70 \%$ and $30-50 \%$, respectively (Meyers et al., 2008). A look at the waste streams could provide a better view. Kitchen waste were mainly composed of bananas, pineapple peals, water melon and food craps rich in carbohydrates, fats and proteins; the manure stream was composed of manure freshly collected from poultry house and pig house respectively. In feed stream where nutrients are in right proportions, pre-pupae respond well (Barry, 2004). The actual composition generated by kitchen waste was not known 
because of the variety and inconstancy of the substrate. On the bad performance of the latter, fruits brought a lot of water in the basins and forced pupae to exit prematurely. During the experiments, we observed that larvae avoided moist areas by climbing out of the basin prematurely. Wheat bran added to those basins was used to absorb humidity and consequently improved the waste reduction in those treatments.

\section{Conclusion}

This study was designed to evaluate the ability of the black soldier fly larvae to digest and degrade various organic wastes building biomass that could be used as animal feed. From the established pilot study, we can conclude that BSF could be used to recycle organic waste in small and medium scale. It has been established that there is a possibility to process and reduce the amounts of wastes, and so it could effectively handle and reduce the organic wastes subjected to it at our facility. Furthermore, the waste reduction in the process comes with compost that could possibly be applied to soils, although this application needs further investigation. The study has gone further to determine that it is possible with the prevailing conditions to generate protein and fat that could be used as a replacement for other protein and fat sources in the stock feed, pet feed and fish farming industries. It must be mentioned, however, that the study also established that the output and feasibility of the reported results will very much depend on the types and quality of organic wastes fed to the larvae, as well as the growth conditions to which they are subjected.

\section{COMPETING INTERESTS}

The authors declare that they have no competing interests

\section{AUTHORS' CONTRIBUTIONS}

PN, JMK, CTK, CTT, JY, BC and FT Conceived and designed the experiments, JY and $\mathrm{BC}$ performed the experiments, PN, JMK, CTK, CTT and TF analyzed and interpreted the data. All the authors read and approved the final manuscript.

\section{ACKNOWLEDGEMENTS}

The authors wish to thank Alexander Maina, Gilbert Langat and Justine Hidzem Manedji for their technical support.

\section{REFERENCES}

Antunes LFS, Scoriza RN, Silva DG, Correia MEF. 2016. Production and efficiency of compost generated by millipede activity. Cienc. Rural., 46(5): 815-819. DOI: http://dx.doi.org/10.1590/0103$8478 \mathrm{cr} 20150714$

Banks IJ. 2010. Determination of physical and biochemical changes of human faeces, of different dietary origins, and black soldier fly larvae (Hermetia illucens) as feeding occurs. Diss. (MSc Biol. Control Dis. Vectors) - LSHTM, Univ. London, 1-77.

Banks IJ, Gibson WT, Cameron MM. 2014. Growth rates of black soldier fly larvae fed on fresh human faeces and their implication for improving sanitation. Trop. Med. Int. Health, 19: 14-22. DOI: https://doi.org/10.1111/tmi.12228

Barry T. 2004. Evaluation of the Economic, Social, and Biological Feasibility of Bioconverting Food Wastes with the Black Soldier Fly (Hermetia illucens). $\mathrm{PhD}$. University of North Texas.

Biekre AHT, Tie BT, Dogbo DO. 2018. Caractéristiques physico-chimiques des composts à base de sous-produits de ferme Songon en Côte d'Ivoire. Int. J. Biol. Chem. Sci., 12(1): 596-609. DOI: https://dx.doi.org/10.4314/ijbcs.v12il.45

Bloukounon-Goubalan AY, Saidou A, Clottey V, Chrysostome CAAM, Kenis M, Mensah GA. 2017. Typology of organic residues attracting flies and their utilization in the agricultural sector in southern Benin. Int. J. Biol. Chem. Sci., 11(6): 2560-2572. DOI: https://dx.doi.org/10.4314/ijbcs.v11i6.1

Cickova H, Newton GL, Lacy RC, Kozanek M. 2015. The use of fly larvae for 
organic waste treatment. Waste Manag., 35: 68-80. DOI: https://doi.org/10.1016/j.wasman.2014.0 9.026

Diener S, Studt Solano NM, Roa Gutierrez F, Zurbrugg C, Tockner K. 2011. Biological treatment of municipal organic waste using black soldier fly larvae. Waste Biomass Valori., 2: 357363. DOI: https://doi.org/10.1007/ s12649-011-9079-1

Diener S, Zurbrugg C, Tockner K. 2009. Conversion of organic material by black soldier fly larvae: establishing optimal feeding rates. Waste Manag. Res., 27: 603-610. DOI: https://doi.org/10.1177/ 0734242 X09103838

FAO. 2006. Livestock Impacts on the Environment. Available at: http://www. fao.org/ag/magazine/0612sp1.htm

FAO. 2009. High Level Expert Forum - How to Feed the World in 2050. Office of the Director, Agricultural Development Economics Division Economic and Social Development Department, Food and Agriculture Organization of the UN (FAO): Rome.

Fomekong TAM, Kana JR, Ngouana TR, Mube KH, Teguia A. 2018. Effets du taux de la lysine et de la methionine de la ration sur les performances de croissance de la poule Barrée du Cameroun. Int. J. Biol. Chem. Sci., 12(2): 927-939. DOI: https://dx.doi.org/10.4314/ijbcs.v12i2.24

IFAD. 2012. The Future of World Food and Nutrition Security: Investing in Smallholder Agriculture - an International Priority. International Fund for Agricultural Development, Rome, Italy.

Li Q, Zheng LY, Cai H, Garza E, Yu ZN, Zhou SD. 2011. From organic waste to biodiesel: black soldier fly, Hermetia illucens, makes it feasible. Fuel, 90: 1545-1548. DOI: https://doi.org/ 10.1111/tmi. 12228
Meyers, HM, Tomberlin, JK, Lambert BD, Kattes D. 2008. Development of black soldier fly (Diptera: Stratiomyidae) larvae fed dairy manure. Environ. Entomol., 37: 11-15. DOI: https://doi.org/10.1603/EN10126

Nguyen TT, Tomberlin JK, Vaniaerhoven S. 2015. Ability of black soldier fly (Diptera: Stratiomyidae) larvae to recycle food waste. Environ. Entomol., 44(2): $\quad 406-410$. DOI: https://doi.org/10.1093/ee/nvv002

Nyadjeu P, Djopnang JD, Mbatchou PN, Tabi-Tomedi, Tchoumbougnang F. 2018. Effect of fish meal substitution with lima bean meal on the growth and feed utilization in common carp fry, Cyprinus carpio. Int. J. Biol. Chem. Sci. 12(2): $\quad 812-821$. DOI: https://dx.doi.org/10.4314/ijbcs.v12i2.16

Parsad R. 2005. Transformation of data. In Des. Anal. Agric. Exp. Parsad R Srivastava R, Gupta VK (eds) Indian Agricultural Statistics Research Institute, New Delhi, India; 637-647.

Pathma J, Sakthivel N. 2012. Microbial diversity of vermicompost bacteria that exhibit useful agricultural traits and waste management potential SpringerPlus, 1: $26 . \quad$ DOI: https://doi.org/10.1186/2193-1801-1-26

Rehman KU, Cai M, Xiao X, Zheng L, Wang H, Soomro AA, Zhou Y, Li W, Yu Z, Zhang J. 2017. Cellulose decomposition and larval biomass production from the co-digestion of dairy manure and chicken manure by mini-livestock (Hermetia illuscens L.). J. Environ. Manag., 196: 458-465. DOI: https://doi.org/10.1016/j.jenvman.2017.0 3.047

Suthar S, Singh S. 2008. Vermicomposting waste by using two epigeic earthworms (Perionyx excavates and Perionyx sansibaricus). Int. J. Environ. Sci. Tech., 
5(1): 99-106. DOI: https://doi.org/10.1007/BF03326002

Simpson SJ, Sword GA, Lorch PD, Couzin ID. 2006. Cannibal crickets on a forced march for protein and salt. Proceedings of the National Academy of Sciences of the United States of America, 103: 4152 4156. DOI: https://doi.org/10.1073/ pnas.0508915103

Tomberlin JK, Adler PH, Myers HM. 2009. Development of the black soldier fly (Diptera: Stratiomyidae) in relation to temperature. Environ. Entomol., 38: 930-934. DOI: https://doi.org/10.1603/ 022.038.0347

van Huis A. 2013. Potential of Insects as Food and Feed in Assuring Food Security. Ann. Rev. Entomol., 58: 563-583. DOI: https://doi.org/10.1146/ annurev-ento120811-153704

Wright GA, Simpson SJ, Raubenheimer D, Stevenson PC. 2003. The feeding behavior of the weevil, Exophthalmus jekelianus, with respect to the nutrients and allelochemicals in host plant leaves. Oikos, 100: 172-184. DOI: https://doi.org/10.1034/j.16000706.2003.11270.x

Zhou F, Tomberlin JK, Zheng L, Yu Z, Zhang J. 2013. Developmental and waste reduction plasticity of three black soldier fly strains (Diptera: Stratiomyidae) raised on different livestock manures. $J$. Med. Entomol., 50(6): 1224-1230. DOI: https://doi.org/10.1603/ME13021. 